\title{
Maruca vitrata (Fab.) [Lepidoptera: Pyralidae] Damage on Cowpea (Vigna unguiculata L. Walp.) in Katsina, Sudan Savanna, Nigeria: The Role of IPM
}

\author{
Abdulhadi Muhammad ${ }^{1, *}$, Anna Mohammed Malgwi², Hycenth Nahunnaro ${ }^{2}$ \\ ${ }^{1}$ Department of Crop Production and Protection, Federal University Dutsin-ma, Dutsin-ma, Nigeria \\ ${ }^{2}$ Department of Crop Protection, Modibbo Adama University of Technology, Yola, Nigeria \\ Email address: \\ amuhammad1@fudutsinma.edu.ng (A. Muhammad), annamalgwil@gmail.com (A. M. Malgwi), \\ hycenth.nahunnaro@yahoo.com (H. Nahunnaro) \\ ${ }^{*}$ Corresponding author
}

\section{To cite this article:}

Abdulhadi Muhammad, Anna Mohammed Malgwi, Hycenth Nahunnaro. Maruca vitrata (Fab.) [Lepidoptera: Pyralidae] Damage on Cowpea (Vigna unguiculata L. Walp.) in Katsina, Sudan Savanna, Nigeria: The Role of IPM. Biochemistry and Molecular Biology.

Vol. 4, No. 6, 2019, pp. 86-93. doi: 10.11648/j.bmb.20190406.12

Received: June 16, 2019; Accepted: July 8, 2019; Published: December 30, 2019

\begin{abstract}
A combination of intra-row spacings, sowing dates, and pesticides on cowpea damage and control caused by $M$. vitrata was carried out towards developing an integrated pest management of $M$. vitrata on cowpea. The experiment was laid out in split-split plot design. Intra-row spacing and sowing dates were respectively allocated to the main and sub-plot while pesticides were allocated to the sub-sub-plot. The treatments were randomized and replicated three times. Data collected were subjected to the analysis of variance and means were separated using LSD at 5\%. The result showed that varying intra-row spacings did not have any significant effect $(\mathrm{P}>0.05)$ on cowpea flower damage by $M$. vitrata at 10 WAS in all the years and the combine except in 2016. Close spacing was observed to record the least flower damage. Early sowing was observed to significantly $(\mathrm{P}<0.05)$ recorded the highest percentage flower damage in all the years and the combine $(22.95,22.78$ and 22.85). Pesticide treated plots $(13.06,13.06$ and 11.67) significantly $(\mathrm{P}<0.05)$ recorded the least percentage flower damage compared with the control plots (26.30). The effect of pesticides was statistically similar, however plots treated with Cyper diforce during recorded the least percentage flower damage. There was no significant difference on the effect of varying intrarow spacing on percentage cowpea pod damaged by $M$. vitrata 10 WAS. However, delay in sowing to SD3 significantly recorded least percentage pod damage $(4.89,14.03$ and 2.94) than early sowing SD1 $(24.47,30.14$ and 12.74) which recorded the highest. The effect of pesticides showed that plots treated with MaviMNPV significantly $(\mathrm{P}<0.05)$ recorded the least percentage damage (6.69) compared with the control (13.08). However, treatments effects were statistically similar. The effect of varying sowing dates showed that sowing cowpea at SD3 significantly $(\mathrm{P}<0.05)$ reduce dried cowpea pod damage at harvest (5.55\% and 6.81\%) than early sowing SD1 (12.85\% and 10.61\%) during 2016 and the combine respectively. It is therefore recommended that varying sowing date and use of Cyper diforce reduce cowpea damage in the study area and is hereby recommended.
\end{abstract}

Keywords: Maruca vitrata, Damage, Cowpea, Bio-pesticide and Integrated Pest Management

\section{Introduction}

Cowpea (Vigna unguiculata L. Walp.), is a dicotyledonous plant belonging to the family Fabacea. It is one of the ancient crops known to man. It is one of the most important crops in Africa cultivated by peasant farmers as a subsistence crop. The crop originated from Africa and spread through
Egypt and domesticated in parts of Southern, Eastern and Western Africa where a large number of primitive cultivars and semi wild forms were found [1--3] stated that cowpea is grown mainly in the savanna regions of the tropics and subtropics in Africa, Asia and South America. According to [4], cowpea is considered as the most important grain legumes in the dry savannas of tropical Africa, where it is grown on 
more than 12.8 million hectares of land. Highly rich in quality protein and has energy content almost equivalent to that of cereal grain. The dried seeds of cowpea provide an inexpensive source of protein in many diets of urban and rural people in the tropics and sub-tropics $[2,5]$. The crop is a good source of quality fodder for livestock and provides cash income. [6] reported that nearly 200 million people of Africa consume the crop. The productivity of this crop is under threats by many biotic and abiotic factors, most importantly the legume pod-borer, M. vitrata. It is one of the most important pests of grain legume throughout the tropics and sub-tropics of Central and South America, Asia and Africa [7-9] identified the borer among the most important grain legume pests in the northern Nigeria. The production of cowpea has continued to decline due to activities of wide spectra of insect pests, notably damage caused by $M$. vitrata. Severe infestation by the borer can cause up to $80 \%$ yield losses $[4,7,6]$. Cowpea losses due to pests attack or diseases can be as high as $90 \%[10,3]$.

Management of insect pests of cowpea can be achieved through varying sowing date or intra-row spacing. Manipulation of sowing date in order to escape period of high insect populations in insect pest management in cowpea was extensively studied $[11,12,2]$. Plant density can also be a strategy in cowpea insect pest control. Close spacing increases plant population per unit space. According to [13], high plant population increase denser canopies which improve the crop micro climate. The improvement in the micro climate will as well increase the population of biocontrol agents which predates/parasitize $M$. vitrata. The use of chemical as means of pest control measures proved effective on cowpea pests. However, its high cost coupled with its potential hazards to the environment, humans, animals and livestock have necessitated the search for viable non chemical methods to reduce the consequences generally caused by pests. Pesticides not only cause environmental pollution especially by non-biodegradable, highly persistent residues, but they also off-set the dynamic equilibrium in aquatic ecosystem [14]. It also affect non target soil micro and macro fauna and flora, predatory beetles, spiders, birds, insect pollinators and other wild life. Besides, they ramify every nooks and corners of aquatic and terrestrial food chains and the more complex food webs [8, 15,9] observed that farmers who adopted control through chemical sprays are exposed to serious health hazards. Search for a viable and environmentally friendly control measure within the reach of economic resource-poor farmers is necessary in order to reduce losses suffered by cowpea farmers. No single strategy can achieve control of major cowpea pest complexes and notably $M$. vitrata. [16] opined that the use of microbial biopesticides especially fungus has been tried with successes mostly in the stored products. Recent, the use of microbial biopesticides in $M$. vitrata control using the Maruca vitrata multi-nucleopolyhedrovirus (MaviMNPV) has been demonstrated [17]. Control of $M$. vitratais crucial for sustainable cowpea production. The research was carried out in order to determine the effect of varying intra-row spacings and sowing dates and use of pesticides on the damage caused by $M$. vitrata on cowpea in Sudan savanna.

\section{Materials and Methods}

\subsection{Study Area}

A field trial was conducted during the cropping season of 2015 and 2016 in the Teaching and Research Farm, College of Agriculture, Hassan Usman Katsina Polytechnic, Latitudes $11^{\circ} 07^{\prime} 49^{\prime \prime}$ to $13^{\circ} 22^{\prime} 57^{\prime \prime} \mathrm{N}$ and Longitudes $06^{\circ} 52^{\prime} 03^{\prime \prime}$ and $09^{\circ} 02^{\prime} 40^{\prime \prime} \mathrm{E}$ and $619 \mathrm{~m}$ above sea level in the Sudan savanna ecological zone [18]. The soil of the area is sandy loam. The rainy season starts from May and ends in October with mean annual rainfall of $742 \mathrm{~mm}$. The State has a total land mass of $24,192 \mathrm{~km}^{2}$ with an estimated population of $6,483,429$ [19]. The inhabitants are Hausa-Fulani and predominantly farmers. The major crops grown include maize, sorghum, millet, rice, cotton, groundnut, sesame, soya bean and cowpea [20].

\subsection{Sources and Preparation of Plant Materials}

\subsubsection{Neem Kernels Seed Extract}

Matured and ripe neem seeds were collected immediately after rainfall in neem tree forest reserve outskirts of Katsina town. The fruits were de-pulped, washed in a bucket containing clean water and subsequently dried under the shade. The seeds were cracked and the kernels removed and were ground using an electric blender (Model: DJ-BL242 manufactured by DAICHI Home essentials). About $5 \mathrm{~kg} \mathrm{ha}^{-1}$ of kernels powdertogether with $2 \mathrm{~kg} \mathrm{ha}^{-1}$ bar soap as emulsifier were wrapped in a clean white cloth and soaked overnight in a bucket containing 100 litre ha- ${ }^{-1}$ of water [21]. The mixture was stirred thoroughly and was squeezed the next day until milky suspension was produced [22- 23]. Gum arabic was added to the filtrate at the rate of $2.7 \mathrm{~kg}$ in 6.75 litres of water ha ${ }^{-1}$ as sticker [1]. This forms the crude extract.

\subsubsection{Maruca Vitrata Multi-nucleopolyhedrosis Virus (MaviMNPV) Suspension}

Maruca vitrata Multi-nucleopolyhedrosis virus (MaviMNPV) suspension was obtained from IITA, Cotonou, Benin Republic.

\subsubsection{Cyperdiforce ${ }^{\circledR}$}

A systemic, contact and stomach poison insecticide belonging to toxicity class II. It is composed of $30 \mathrm{~g} \mathrm{~L}^{-1}$ Cypermethrin and $250 \mathrm{~g} \mathrm{~L}^{-1}$ Dimethoate EC (Systemic pyrethroid for cypermethrin, organophosphate for Dimethoate) manufactured by Jubaili Agrotech. The insecticide was applied at the rate of $1.5 \mathrm{~L} \mathrm{ha}^{-1}$ in $925 \mathrm{~L}$ of water using Knapsack CP-3 sprayer having hollow cone nozzle type [12].

\subsection{Treatments and Experimental Design}

The treatments consisted of three Intra-row spacings, three sowing dates and three pesticides (of which included two biopesticides and a synthetic check) and a control. The 
experiment was laid out using Split-split-plot design with Intra-row spacing (Factor A) SP1; 75 × $20 \mathrm{~cm}, \mathrm{SP} 2 ; 75 \times 30$ $\mathrm{cm}$ and SP3; $75 \times 40 \mathrm{~cm}$ allocated to the main plot, sowing date (Factor B) (SD1; 02 July, SD2; 23 July, SD3; 13 August) allocated to the sub plot and pesticides (Factor $\mathrm{C}$ ); neem kernel seeds extract (NKE) (P1), MaviMNPV suspension (P2) and Cyper diforce (P3) and the control (P0) were allocated to the sub-sub-plot. The treatments were randomized and replicated three times. Each plot consisted of six ridges of $6 \mathrm{~m}$ long and $4.5 \mathrm{~m}$ wide. The ridges were 0.75 $\mathrm{m}$ apart. The two middle rows constituted the net plot, the second and fifth rows for sampling while first and sixth rows constituted boarders [1]. The blocks were separated by unplanted space of $2 \mathrm{~m}$ while $1 \mathrm{~m}$ was left between plots. A distance of $1 \mathrm{~m}$ was also left between main plots. The trial was repeated during the same date in 2016.

\subsection{Cultural Practices}

The area was harrowed and ridged using tractor. Cowpea variety SAMPEA 7 which is susceptible to $M$. vitrata infestation and widely grown in the ecological zone was planted. Allstar ${ }^{\circledR} 40$ SD, a seed dressing chemical consisting of $20 \%$ Metalaxyl and 20\% limidacloprid was used at the rate of one sachet per $4 \mathrm{~kg}$ of seeds was used to dress the seeds prior to planting against soil-borne diseases and insect pests [22]. Sowing was varied at three weeks interval. A day prior to sowing, the sub plot was weeded. Three cowpea seeds were sown per hole and later thinned to two seedlings per stand [24]. Single super phosphate fertilizer was applied at the rate of $6.75 \mathrm{~g}$ to each plot immediately after sowing. Mancozeb $80 \%$ as Z-force (family of ethylene Bisdithiocarbamate) was applied at the rate of $0.891 \mathrm{~g}$ in $2.5 \mathrm{~L}$ water per each plot against fungal diseases when symptoms of diseases were observed. Weeding was carried out at 3 and 6 weeks after sowing (WAS) [25]. Gap filling was done at three weeks after germination to replace dead seedlings [8].

\subsection{Treatments Application}

Field applications of neem kernels seeds extract and the insecticide was achieved using 2 different 20 litre CP3 Knapsack sprayer. The viral suspension was applied using hand operated manual sprayer. Treatments application commenced at 7 WAS (49 days) which coincided with the period of onset of flowering in the variety (vegetative phase) [23-24]. Foliar spraying was done between 06:00 to 07.00 a.m. each day. All the treatments were sprayed once every week for four weeks according to [24].

\subsection{Data Collection}

\subsubsection{Assessment of M. vitrata Damage in Flowers 24 Hrs Before and After Treatment}

Twenty flower buds or flowers depending on the stage of growth were randomly sampled from four plants (five each) between $3^{\text {rd }}$ and $10^{\text {th }}$ stand per plot for assessment of $M$. vitrata population $24 \mathrm{hrs}$ before and after treatment [26]. The flowers were placed in vials containing $30 \%$ alcohol to allow dislodgement of larvae and were dissected the following day [27]. The sampled flowers were examined based on damage such as presence of entry/exit holes, presence of dirty frass/excretes or life/dead larvae [28, 29-30]. The flowers were dissected and observed and numbers of larvae found in each flower were counted and recorded.

\subsubsection{M. vitrata Pod Damage Assessment 24 Hrs Before and After Treatment}

Pod damage assessment was determined through destructive sampling. Twenty pods were randomly examined 10 WAS from five plants from four stands for $M$. vitrata damage per net plot. The pods were placed in large brown (35 x $25 \mathrm{~mm})$ envelops for laboratory assessment of the parameter. Pod damaged were examined based on presence of entry/exit holes, frass deposition as well as presence of life or dead larva. Borer damaged pods were separated from the undamaged ones. The percentage pod damage was expressed as total number of damaged pods divided by the total number of pods harvested multiplied by 100 [28].

Dried pod damage at harvest was assessed by separating the damaged pods due to Maruca from that of complex of pod sucking bugs. The bug damage pods were shriveled, twisted, stunted and constricted [8].

\subsection{Data Analysis}

Data obtained were subjected to analysis of variance (ANOVA). Means with significant differences were separated using LSD at $\mathrm{P} \leq 0.05$ using [31] statistical package. Prior to analysis, data with zero values were subjected to transformation using $\sqrt{ } \mathrm{n}+0.5$.

\section{Results}

Varying intra-row spacing on post spray percentage flower damage by $M$. vitrata in all the years and the combined except at 10 weeks after sowing (WAS) in 2016. Highly significant $(\mathrm{P} \leq 0.01)$ difference was observed to record lower flower damage in closely spaced cowpea (14-15) (SP1). Although, the effect was statistically similar with cowpea sown at $75 \times 30 \mathrm{~cm} \mathrm{SP2} \mathrm{(15.28).} \mathrm{Significantly} \mathrm{higher} \mathrm{flower}$ damage was obtained in wider spaced cowpea $75 \times 40 \mathrm{~cm}$ SP3 (20.14) (Table 1). Varying sowing dates on percentage flower damage showed that there was high significant $(\mathrm{P} \leq 0.01)$ difference on mean flower damage among the three sowing dates. Cowpea sown on $2^{\text {nd }}$ July significantly $(\mathrm{P} \leq 0.05)$ recorded the highest damage in all the periods of sampling while cowpea sown on $13^{\text {th }}$ August recorded the least damage in 2015, 2016 and the combined. The highest percentage flower damage was recorded in cowpea sown in $2^{\text {nd }}$ July (25.28) at 8 WAS and $13^{\text {th }}$ August recorded the lowest percentage (5.69) at the same sampling. The effect of NKE, MaviMNPV and Cyper diforce on post spray percentage flower damage was significantly different $(\mathrm{P} \leq 0.05)$ at 8 WAS in 2015. Although, the effectiveness of the treatments were statistically similar and comparable, 
Cyper diforce was most toxic/potent. The control plots significantly $(\mathrm{P} \leq 0.05)$ recorded the highest flower damage in all the sampling periods. The highest percentage damage in the control plots was obtained at 10 WAS in 2016 (34.26) while the least flower damage (7.96) was recorded in the plot treated with Cyper diforce in the same year (Table 1).

Table 1. Effect of IPM on post spray cowpea flower damaged by M. vitrata on flowers sampled 8, 9 and 10 WAS.

\begin{tabular}{|c|c|c|c|c|c|c|c|c|c|}
\hline Treatments & 8 WAS & 9 WAS & 10 WAS & 8 WAS & 9 WAS & 10 WAS & 8 WAS & 9 WAS & $10 \mathrm{WAS}$ \\
\hline Intra-row spacing $(\mathrm{cm})(\mathrm{SP})$ & 2015 & & & 2016 & & & Combined & & \\
\hline SP1: $75 \times 20$ & 19.86 & 15.42 & 15.83 & 13.33 & 20.28 & $15.14^{\mathrm{b}}$ & 16.60 & 17.85 & 15.49 \\
\hline SP2: $75 \times 30$ & 17.22 & 16.39 & 16.11 & 13.47 & 18.06 & $15.28^{\mathrm{b}}$ & 15.35 & 17.22 & 15.69 \\
\hline SP3: $75 \times 40$ & 16.67 & 14.44 & 14.58 & 13.89 & 16.11 & $20.14^{\mathrm{a}}$ & 15.28 & 15.28 & 17.36 \\
\hline Mean & 17.92 & 15.42 & 15.51 & 13.56 & 18.15 & 16.85 & 15.74 & 16.78 & 16.18 \\
\hline LSD & 3.315 & 2.179 & 3.610 & 3.125 & 5.805 & 3.598 & 2.604 & 3.884 & 2.414 \\
\hline \multicolumn{10}{|l|}{ Sowing dates (SD) } \\
\hline $23^{\text {rd }}$ July & $22.78^{\mathrm{a}}$ & $13.75^{\mathrm{b}}$ & $14.31^{\mathrm{b}}$ & $13.61^{\mathrm{b}}$ & $23.61^{\mathrm{a}}$ & $14.17^{\mathrm{b}}$ & $18.19^{\mathrm{b}}$ & $18.68^{\mathrm{b}}$ & $14.24^{\mathrm{b}}$ \\
\hline $13^{\text {th }}$ Aug. & $5.69^{\mathrm{b}}$ & $7.22^{\mathrm{c}}$ & $9.31^{\mathrm{b}}$ & $7.08^{c}$ & $11.11^{\mathrm{b}}$ & $13.61^{\mathrm{b}}$ & $6.39^{c}$ & $9.17^{\mathrm{c}}$ & $11.46^{\mathrm{b}}$ \\
\hline Mean & 17.92 & 15.42 & 15.51 & 13.56 & 18.15 & 16.85 & 15.74 & 16.78 & 16.18 \\
\hline LSD & 3.658 & 4.189 & 4.109 & 4.408 & 7.484 & 8.241 & 2.452 & 3.536 & 3.676 \\
\hline \multicolumn{10}{|l|}{ Pesticides (P) } \\
\hline P1: Neem seed kernel extract & 16.85 & $12.78^{\mathrm{a}}$ & $15.37^{\mathrm{ab}}$ & $10.56^{\mathrm{b}}$ & $15.74^{\mathrm{b}}$ & $12.04^{\mathrm{b}}$ & $13.70^{\mathrm{b}}$ & $14.26^{\mathrm{b}}$ & $13.06^{\mathrm{b}}$ \\
\hline P2: MaviMNPV suspension & 16.11 & $15.00^{\mathrm{b}}$ & $12.96^{\mathrm{b}}$ & $11.30^{\mathrm{b}}$ & $16.85^{\mathrm{b}}$ & $13.15^{\mathrm{b}}$ & $13.70^{\mathrm{b}}$ & $15.93^{\mathrm{b}}$ & $13.06^{\mathrm{b}}$ \\
\hline P3: Cyper diforce & 19.07 & $14.63^{\mathrm{b}}$ & $15.37^{\mathrm{ab}}$ & $8.52^{\mathrm{b}}$ & $8.15^{\mathrm{c}}$ & $7.96^{\mathrm{c}}$ & $13.80^{\mathrm{b}}$ & $13.70^{\mathrm{b}}$ & $11.67^{\mathrm{b}}$ \\
\hline Mean & 17.92 & 15.42 & 15.51 & 13.56 & 18.15 & 16.85 & 15.74 & 16.79 & 16.18 \\
\hline LSD & 4.206 & 3.496 & 3.685 & 3.747 & 5.513 & 3.269 & 2.784 & 3.27 & 2.435 \\
\hline \multicolumn{10}{|l|}{ Interactions } \\
\hline SD x SP & NS & NS & NS & NS & NS & NS & NS & NS & NS \\
\hline $\mathrm{SD} \times \mathrm{P}$ & $* *$ & $*$ & NS & $* *$ & NS & $* *$ & $* *$ & NS & $* *$ \\
\hline SP $x \mathrm{P}$ & NS & NS & NS & NS & NS & NS & NS & NS & NS \\
\hline $\mathrm{SD} \times \mathrm{SP} \times \mathrm{P}$ & NS & NS & NS & NS & NS & NS & NS & NS & NS \\
\hline
\end{tabular}

Means with the same letter (s) in the same column are not significantly different using LSD at $5 \%$ level, NS $=$ not significant, $*$ significant at $P \leq 0.05, * *=$ highly significant at $P \leq 0.01$, WAS $=$ weeks after sowing, $\mathrm{SD}=$ Sowing dates, $\mathrm{SP}=$ Intra-row spacing, $\mathrm{P}=\mathrm{Pesticides}$.

Highly significant $(\mathrm{P} \leq 0.05)$ difference on percentage cowpea pod damaged by $M$. vitrata was observed among the three sowing dates. Higher damage was recorded in cowpea sown in $2^{\text {nd }}$ July which significantly differs with that sown in $13^{\text {th }}$ August. Cowpea sown on the $2^{\text {nd }}$ July recorded higher pod damage $(12.74 \%)$ compared with that sown on the $23^{\text {rd }}$ July SD2 (3.64\%) and that of $13^{\text {th }}$ August (2.94\%) which were statistically similar. The result of the effect of pesticides on percentage cowpea pod damage at 10 WAS varied (Table 2). Statistically similar effects were observed among the pesticides. However, their effectiveness were significantly $(\mathrm{P} \leq 0.05)$ superior than the control which recorded the highest pod damage (39.44\%).

The result of the effect of varying sowing dates on percentage cowpea pod damage at harvest (Table 3). Highly significant $(P \leq 0.01)$ difference was observed in varying sowing dates on percentage pod damaged by $M$. vitrata recorded at harvest. Significantly lower pod damage was recorded in cowpea sown on the $13^{\text {th }}$ August during 2016 cropping season and the combine $(6.81 \%)$. However, high pod damage was obtained in cowpea sown on the $2^{\text {nd }}$ July $(10.61 \%)$.

High percentage pod damage at harvest was recorded in the control plots in all the years and the combined (13.08). The effectiveness of the pesticides was however statistically similar except during 2015 cropping season. Plots treated with Cyperdiforce recorded lower percentage pod damage (5.07) compared with NKE (10.42) and MaviMNPV (7.57) plots. The performance of MaviMNPV was comparable to Cyperdiforce in all the years and the combined.

Table 2. Effect of intra-row spacings, sowing dates and pesticides on percentage cowpea pod damage by M. vitratasampled 10 WAS during 2015 and 2016 cropping seasons.

\begin{tabular}{lccc}
\hline Treatments & $\mathbf{2 0 1 5}$ & $\mathbf{2 0 1 6}$ & Combined \\
\hline Intra-row spacings (cm) (SP) & & & 5.79 \\
SP1: 75 x 20 & 10.58 & 25.83 & 6.83 \\
SP2: 75 x 30 & 12.67 & 24.17 & 6.69 \\
SP3: 75 x 40 & 12.39 & 25.00 & 6.44 \\
Mean & 11.88 & 25.00 & 1.496 \\
LSD & 3.159 & 4.759 & $12.74^{\mathrm{a}}$ \\
Sowing dates (SD) & & & $3.64^{\mathrm{b}}$ \\
$2^{\text {nd }}$ July & $24.47^{\mathrm{a}}$ & $30.14^{\mathrm{a}}$ & $2.94^{\mathrm{b}}$ \\
$3^{\text {rd } J u l y ~}$ & $6.28^{\mathrm{b}}$ & $30.83^{\mathrm{a}}$ & 6.44 \\
13 & $4.89^{\mathrm{b}}$ & $14.03^{\mathrm{b}}$ & 2.031 \\
Mean & 11.88 & 25.00 & \\
LSD & 3.752 & 8.819 & \\
\hline
\end{tabular}




\begin{tabular}{llll}
\hline Treatments & $\mathbf{2 0 1 5}$ & $\mathbf{2 0 1 6}$ & Combined \\
\hline Pesticides (P) & & & \\
P1; Neem seeds kernels extract & $11.97^{\mathrm{ab}}$ & $20.74^{\mathrm{b}}$ & 6.46 \\
P2: MaviMNPV suspension & $10.26^{\mathrm{b}}$ & $20.37^{\mathrm{b}}$ & 5.63 \\
P3: Cyper diforce & $11.37^{\mathrm{ab}}$ & $19.44^{\mathrm{b}}$ & 7.19 \\
P0: Control & $13.37^{\mathrm{a}}$ & $39.44^{\mathrm{a}}$ & 6.44 \\
Mean & 11.88 & 25.00 & 1.647 \\
LSD & 3.331 & 5.503 & $\mathrm{NS}$ \\
Interactions & & & $\mathrm{NS}$ \\
SD x SP & $\mathrm{NS}$ & $\mathrm{NS}$ & $\mathrm{NS}$ \\
SD x P & $\mathrm{NS}$ & $\mathrm{NS}$ \\
SP x P & $\mathrm{NS}$ & $\mathrm{NS}$ & $\mathrm{NS}$ \\
SD x SP x P & $\mathrm{NS}$ & & \\
\hline
\end{tabular}

Means with the same letter (s) in the same column are not significantly different using LSD at 5\% level, NS-not significant, SD - Sowing dates, SP -Intra-row spacings, P-Pesticides.

Table 3. Effect of intra-row spacings, sowing dates and pesticides on percentage cowpea pods damage by M. vitrata at harvest during 2015 and 2016 cropping season.

\begin{tabular}{|c|c|c|c|}
\hline Treatments & 2015 & 2016 & Combined \\
\hline \multicolumn{4}{|l|}{ Intra-row spacing $(\mathrm{cm})(\mathrm{SP})$} \\
\hline SP1: $75 \times 20$ & 9.04 & 8.80 & 8.92 \\
\hline SP2: $75 \times 30$ & 8.88 & 7.74 & 8.31 \\
\hline SP3: $75 \times 40$ & 9.29 & 9.25 & 9.27 \\
\hline Mean & 9.07 & 8.59 & 8.83 \\
\hline LSD & 1.970 & 2.698 & 1.582 \\
\hline \multicolumn{4}{|l|}{ Sowing dates (SD) } \\
\hline $2^{\text {nd }}$ July & 10.76 & $12.85^{\mathrm{a}}$ & $10.61^{\mathrm{a}}$ \\
\hline $23^{\text {rd }}$ July & 8.38 & $7.38^{\mathrm{ab}}$ & $9.07^{\mathrm{ab}}$ \\
\hline $14^{\text {th }}$ Aug. & 8.07 & $5.55^{\mathrm{b}}$ & $6.81^{\mathrm{b}}$ \\
\hline Mean & 9.07 & 8.59 & 8.83 \\
\hline LSD & 4.831 & 6.109 & 3.141 \\
\hline \multicolumn{4}{|l|}{ Pesticides $(\mathrm{P})$} \\
\hline P1: Neem seeds kernels extract & $10.42^{\mathrm{b}}$ & $7.32^{\mathrm{b}}$ & $8.87^{\mathrm{b}}$ \\
\hline P2: MaviMNPV suspension & $7.57^{\mathrm{c}}$ & $5.80^{\mathrm{b}}$ & $6.69^{\mathrm{b}}$ \\
\hline P3: Cyper diforce & $5.07^{\mathrm{c}}$ & $8.31^{\mathrm{b}}$ & $6.69^{\mathrm{b}}$ \\
\hline P0: Control & $13.23^{\mathrm{a}}$ & $12.94^{\mathrm{a}}$ & $13.08^{\mathrm{a}}$ \\
\hline Mean & 9.07 & 8.59 & 8.83 \\
\hline LSD & 2.516 & 3.756 & 2.235 \\
\hline \multicolumn{4}{|l|}{ Interactions } \\
\hline SD x SP & NS & NS & NS \\
\hline SD x P & NS & NS & NS \\
\hline $\mathrm{SP} \times \mathrm{P}$ & NS & NS & NS \\
\hline SD $\times S P \times P$ & NS & NS & NS \\
\hline
\end{tabular}

Means with the same letter (s) in the same column are not significantly different using LSD at 5\% level, NS-not significant, SD - Sowing dates, SP -Intra-row spacing, P-Pesticides.

\section{Discussions}

Result from this study shows that varying intra-row spacing in the study area did not show any significant effect on percentage flower damage. However, lower percentage damage was obtained in cowpea spaced $75 \times 30 \mathrm{~cm}$. Similar reports on the non significant effect of plant spacing on the number the insect pests as well as pod damage abounds in literature [32]. The findings of this study is also similar to the results obtained by [33] in a trial conducted in Kano which showed that spacing had no significant effect $(\mathrm{P}>0.05)$ on population of insect pests on cowpea.

There were significant differences in the percentage flower damage among the three sowing dates. The last sowing recorded reduction in flower damage by $M$. vitratacould be due to the variation in the sowing dates. The flowering and podding stages of cowpea sown on $2^{\text {nd }}$ July occurred in the $3^{\text {rd }}$ week of August. The period is associated with high rainfall and humidity favoured by peak period of high densities of $M$. vitrata.

The result of this study on the effect of pesticides indicated that plots sprayed with NKE, MaviMNPV and Cyperdiforce recorded reduction in the percentage flower damage as compared to the control plots. Although, there was no significant difference between the treatments, NKE performed better although statistically similar with Cyperdiforce in reducing flower damage 24 after treatments. This implies that all the tested products are effective means of reducing $M$. vitrata population and damage on cowpea. Though NKE and the control plots did not differ significantly in all the periods of sampling, NKE reduced flower damage better than the control. This finding is similar to the observations of [43] who reported that crude extract of neem applied on bean plants resulted in 
significant reduction in flower damage when compared to the controls. Furthermore, the significant performance of neem relative to the control in suppressing pest populations confirms the earlier work conducted by [35] and [36] who reported insecticidal activities of plant extracts in suppressing populations of various insect pests of cowpea ( $M$. vitrata inclusive) when compared with the control. The potency of NKE seen in this study could be attributed to the reported presence of active ingredients that are insecticidal to cowpea pests. [37] (in press) identified active ingredients in neem that are responsible for insect repellent, insect growth regulation, anti-feeding, oviposition deterrence, sterility, and some residual insecticidal properties on different species of insect pests to be Azadirachtin, nimbin, salanin and meliantriol. Same compounds are also assumed to be present which produces insecticidal effects on $M$. vitratain this particular study.

Furthermore, Cyperdiforce was found to be more effective. The potentials of using neem extract in pest control is still highly plausible, although it is not as effective as Cyperdiforce. Such potentials have been elaborated by several authors who reported the potentials of using neem extract as pesticides [38, 39 and 40]. Cyperdiforce still performed better than MaviMNPV but was statistically at par with NKE. This also revealed the potentials of using NKE as an alternative to Cyperdiforce (synthetic insecticide) in pest control. Similar control can be achieved with NKE considering the hazards posed by synthetic insecticide on the environment, the applicator, beneficial insects, non target organisms and high cost of purchase especially to the low income farmers [9].

Varying intra-row spacing did not have any effect on percentage cowpea pod damage sampled 10 WAS. This finding is in agreement with the report of [32] who reported non-significant difference of the effect of varying plant spacing on cowpea pod damage by insect pests in Abeokuta. This is also similar to the observations of [33] who reported that cowpea pod damage was not significant $(\mathrm{P} \geq 0.05)$ when the plant spacing (intra-row) was varied in Kano.

The result of this study showed that cowpea sown on the $2^{\text {nd }}$ July recorded the highest pod damage by $M$. vitratasampled 10 WAS $(\mathrm{P} \leq 0.01)$. Lower pod damage was recorded in cowpea sown on $13^{\text {th }}$ August than that sown on $23^{\text {rd }}$ July. The reasons for this could be that early sown cowpea flowering and pod formation stages coincided with the period of high population densities of $M$. vitrata as such were heavily attacked. This is similar to the observations of that reported flowering and pod formation of cowpea planted in July and August coincided with peak period of high population densities of post-flowering pests causing much loss in cowpea productivity.

Even though MaviMNPV and NKE reduced cowpea pod damage, Cyperdiforce was superior. However, there was no significant difference among the treatments, the control plots recorded the highest pod damage. This finding agreed with the observations of [41] who observed damage to cowpea pods significantly $(\mathrm{P} \leq 0.05)$ reduced in a synthetic insecticide (mixture of cypermethrin and dimethoate) sprayed plots in the Delmarva (Delaware, Maryland and Virginia) peninsula region of the United States. The performance of MaviMNPV compared with Cyperdiforce showed that the viral suspension is a potential biopesticide which could be use as an alternative to synthetic insecticide. However, using the viral suspension alone did not offer effective control in this study. However, its potency could be improved when used in combination with another control agent [42]. This is in line with the view of [43] who reported combination of azadirachtin and nucleopolyhedrovirus $\left(0.25 \mathrm{ppm}+1 \times 10^{3}\right.$ $\mathrm{OB}$ and $\left.0.5 \mathrm{ppm}+1 \times 10^{6} \mathrm{OB}\right)$ to have resulted in significantly causing higher larval mortality in Spodoptera litura than treatment with either the virus or botanical insecticide alone.

Varying intra-row spacing did not showed significant effect on dry pod damage. However, high plant density (close spacing) favoured high dried pod damage compared to less plant density. This is because cross infestation of $M$. vitrata is facilitated when canopies interlock with one another as reported by [13].

The effect of varying sowing dates in reducing dried cowpea pod damage by cowpea pod-borer showed that delay in cowpea sowing to $23^{\text {rd }}$ July and $13^{\text {th }}$ August although not significantly different but reduced dried pod damage. This showed that podding stages of cowpea sown on $2^{\text {nd }}$ July coincided with the peak population densities of $M$. vitrata. This finding disagreed with the report of [12] that elite cowpea cultivar when planted in June or early July in Kano area, their flowering and podding stages escaped the peak population densities of the three major post-flowering pests which occur from mid-September through to November.

There was no significant difference among NKE, MaviMNPV and Cyperdiforce on dried cowpea pod damage at harvest. Cyperdiforce recorded the least damage while the control recorded the highest pod damage. This finding is consistent with the results obtained by [24] who reported least cowpea pod damage in Uppercott sprayed plots which was closely followed by mixtures of cashew nut shell + West African black pepper thereby reducing pod damage at 10 WAS. The control recorded the highest $(\mathrm{P}<0.05)$ pod damage.

\section{Conclusion}

The result of this study clearly showed that the performance of Maruca vitrata Multi-nucleopolyhedrosis virus (MaviMNPV) suspension as a promising control agent against cowpea pod borer. Its performance was comparable with the Cyber diforce (synthetic insecticide). Further research can be undertaken using the viral suspension alone or in combination with another control agent such as Jatropa or neem seed oil in synegy in the study area or somewhere else.

\section{Acknowledgements}

The authors thanked the contributions of Dr. M. Tamo and 
his co-workers for providing the viral formulation used in this research.

\section{References}

[1] Kwaifa, N. M.; Ibrahim, N. D.; Dike, M. C., Abubakar, M. G. 2012. Bioefficacy of neemand mahogany extracts for control of cowpea flower Thrips, Megaluthrips sjostedti Trybom [Thysanoptera: Thripididae] and Grasshopper, Ailopus simulatrix Walker [Orthoptera: Pyrogomophidae] in sudan savannah, Nigeria. Nigerian Journal of Entomology, 29: 3142.

[2] Ajeigbe, H. A.; Adamu, R. S.; Singh, B. B. 2012. Yield performance of cowpea as influenced by insecticidetypes and their combinations in the dry savannas of Nigeria. African Journal of Agricultural Research. 7 (44): 5930-5938. Available online at http://www.academicjournals.org/AJAR DOI: $10.5897 / A J A R 12.431$

[3] International Institute of Tropical Agriculture (IITA) 2009. Cowpea, Vignaunguiculata. CGIAR. www.iita.org. Accessed $15 / 04 / 2014$

[4] African Agricultural Technology Foundation (AATF) 2011. Pod-borer Resistant Cowpea Project, www.aatf-africa, retrieved 18/01/2014.

[5] Ahmed, B. I.; Onu, I.; Mudi, L. 2009. Field bioefficacy of plant extracts for the control of post flowering insect pests of cowpea, Vigna unguiculata (L.) Walp. in Nigeria. Journal of Biopesticides, 2 (1): 37-43.

[6] African Agricultural Technology Foundation (AATF) 2014. Pod-borer resistant cowpea project partnership-developing a pod-borer resistant cowpea. www.aatf-africa.org.

[7] Agunbiade, T. A.; Coates, B. S.; Kim, K. S.; Forgacs, D.; Margam, V. M.; Murdock, L. L.; et al. 2012. The spatial genetic differentiation of the legume pod-borer, Maruca vitrata $\mathrm{F}$. (Lepidoptera: Crambidae) populations in West Africa. Bulletin of Entomological Research, 1-11.

[8] Ogah, E. O. 2013. Field evaluation of plant extracts in the management of Megalurothrips sjostedti and Maruca vitrata of cowpea in southeastern Nigeria. World Essays Journal, 1 (1): 11-17. Available online at www. worldessaysj.com.

[9] Oyewale, R. O.; Bamaiyi, L. J.; Oparaeke, A. M.; Adamu, R. S. 2014. Evaluation of four insecticide formulations for the management of insect pests of cowpea. African Journal of Food Science and Technology, 5 (8): 180-188. DOI: http:/dx.doi.org/10.14303/ajfst.2014.101.

Retrieved on $13 / 07 / 2016$.

[10] Lambot, C. 2002. Industrial potential of cowpea. Agriculture raw material, Nestle Research Center, Abidjan, Côte d'voire. pp. 367-375.

[11] Nabirye, J.; Nampala, P.; Ogenga-Latigo, M. W.; Kyamanywa, S.; Wilson, H.; Odeke, V.; Iceduna, C.; Adipala, E. 2003. Farmer-participatory evaluation of cowpea integrated pest management (IPM) technologies in Eastern Uganda. Crop Science, 22: 31-38.

[12] Asante, S. K.; Tamo, M.; Jackai, L. E. N. 2001. Integrated management of cowpea insect pests using elite cultivars, date of planting and minimum insecticide application. African Crop Science Journal, 9 (4): 655-665.
[13] Karungi, J., Nampala, M. P., Adipale, E. S., Kyamanywa and Ogenga, Latigo, M. W. (1999). Intra-row dynamics of selected cowpea insect pest as influenced by different management practices in Eastern Uganda. African Crop Science Journal. 7 (4), 487-495.

[14] Aliyu, M.; Ladan, T.; Ahmed, B. I.; Abdullahi, J. 2007. Studies on the efficacy of black soap and kerosene on the control of pod sucking bugs (Clavigralla tomentosicollis Stal.) on Cowpea (Vigna unguiculata (L.) Walp.). Emirate Journal Food Agriculture, 19 (2): 08-12.

[15] Degri, M. M.; Maina, Y. T.; Richard, B. I. 2012. Effect of plant extracts on post flowering insect pests and grain yield of cowpea (Vigna unguiculata) (L.) Walp.) in Maiduguri, semi arid zone of Nigeria. Journal of Biology, Agriculture and Healthcare, 2 (3): 46-51. ISSN 2224-3208 (Paper) ISSN 2225-093X (Online).

[16] Ahmed, B. I.; Ansari, M. A.; Shah, F. A.; Butt, T. M. 2010. Mass production of the insect-pathogenic fungus, Metarhizium anisopliae (Metchnikoff) Sorokin (Deuteromycota: Hyphomycetes), on different cereal grains. Nigerian Journal of Entomology, 27: 75-81. http://dx.doi.org/10.1080/03235400701390463.

[17] Tamo, M.; Srinivasan, R. 2012. Consultative Group on International Agricultural Research-Systemwide Program on integrated pest management (CGIAR SP-IPM), biological control: new cure for an old problem, technical innovation brief No. 8. August, 2012. IPM Secretariat, Cotonou, Benin Republic. 2PP. www.spipm.cgiar.org. Retrieved on $15 / 02 / 2014$

[18] Ibrahim, Y. E.; Sani, L. I. 2012. The role of information dissemination in attaining food security in Katsina State, Nigeria. Library Philosophy and Practice (e-journal) 826. 1-5

[19] Population Commission (NPC) (2006). National Population Census 2006 data, National Population Commission, Abuja, Nigeria.

[20] MOANR, 2013. Agriculture in Katsina State an overview, a publication of Katsina State Ministry of Agriculture and Natural Resources, Lamp Printing Press, 21pp.

[21] Neem Foundation 2005. Spreading the neem revolution. an informal compilation of some of the investigations and developments done on Neem in the recent pasts. Neem Foundation. www.neemfoundation.org/invest.htm.Retrieved on $07 / 01 / 2005$.

[22] Oparaeke, A. M.; Dike, M. C.; Amatobi, C. I. 2005. Evaluation of Botanical Mixtures for Insect Pests Management on Cowpea Plants. Journal of Agriculture and Rural Development in the Tropics and Subtropics, 106 (1): 41-48.

[23] Oparaeke, A. M. 2006. Effect of aqueous extract of tropical plants for management of Maruca vitrata Fab. And Clavigralla tomentosicollis Stal. on cowpea, Vignaunguiculata (L.) Walp. plants. Journal of Entomology, 3 (1): 70-75.

[24] Oparaeke, A. M.; Dike, M. C.; Amotobi, C. I. 2006. Field evaluation of an extract of five Nigerian species for control of post-flowering pests of cowpea, Vignaunguiculata (L.) Walp. Plant Protection Sciences, 41: 14-20.

[25] Alghali, A. M. 1993. Intercropping as a component in insect pest management for grain cowpea, Vigna unguiculata (Walp) production in Nigeria. Journal of Tropical Insect Science, 14 (1): $50-52$. 
[26] Wudil, B. S., Ahmed, B. I. and Yusuf, S. R. (2013). Field evaluation of two essential oils and a synthetic insecticide for the control of some major insect pests of Cowpea (Vignaunguiculata (L.) Walp in Bauchi State, Nigeria. Nigerian Journal of Entomology. 30, 114-135.

[27] Amatobi, C. I. 1994. Field evaluation of some insecticides for the control of insect pest of Cowpea, Vigna unguiculata (L.) Walp. in Sudan Savanna of Nigeria. International Journal of Pest Management, 40: 13-17.

[28] Oghiakhe, S.; Jackai, L. E. N.; Makanjuola, W. A. 1991. Cowpea plant architecture in relation to infestation and damage by the legume pod borer Maruca testulalis Geyer (Lepidoptera: Pyralidae) - 1: effect of canopy structure and pod position. Insect Science Application, 12 (1/2/3): 193-199.

[29] Asiwe, J. A. N.; Nokoe, S.; Jackai, L. E. N.; Ewete, F. K. 2005. Does varying cowpea spacing provide better protection against cowpea pests, Crop Protection, 24 (5): 465- 471.

[30] Abdullahi, M. M.; Ibrahim, S. K. 2014. Assessment of the effect of time, synthetic and botanical insecticides spray regimes on the abundance of predators in cowpea production in Kebbi State of Nigeria. IOSR Journal of Agriculture and Veterinary Sciences, 7 (5): 87-95.

[31] SAS 2000. SAS Users Guide; version 606, Cary, NC: SAS Institute.

[32] Ajao, F. O.; Osipita, A. A.; Lawal, O. I. 2016. Effect of plant spacing on abundance of major insect pests of cowpea, (Vigna unguiculata (L.) Walp.) and crop yield. [Abstract]. Journal of Organic Agriculture and Environment, 4 (1).

[33] Yusuf, A. U.; Zakari, F. S. 2016. Influence of plant spacing on insect pest infestation and yield of some cowpea (Vigna unguiculata L. Walp.) varieties in Kano, Nigeria. [Abstract]. Journal of Organic Agricultureand Environment. 4 (1).

[34] Rauf, F. M.; Sardar, A. 2011. Effect of crude seed extract of some indigenous plants for the control of legume pod borer (Maruca vitrata F.) on country bean. Bangladesh Journal of Agriculture and Natural Resources, 36 (1): 41-50.

[35] Malgwi, A. M.; Hamman, S. I. 2013. Comparative efficacy of three plant extract as possible bio-pesticides and Cypermethrin on insect pests of cowpea and its yield in Yola, Nigeria. A poster presentation at the $4^{\text {th }}$ International conference of BIOPESTICIDES tagged BIOCICON, 2013 at Tamil Nadu, India. Held on the $28-30^{\text {th }}$ November 2013.

[36] Malgwi, A. M.; Onu, J. I. 2004. Insect pests of cowpea and groundnut in Gerei Local Government, Adamawa State, Nigeria. Nigerian Journal of Entomology, 21 (1): 137-151.

[37] Waiganjo, M. M.; Waturu, C. N.; Mureithi, Muriuki, J. M., Kamau, J., J. and Munene, R. (in press). Use of entomopathogenic fungi and neem bio-pesticides for Brassica pests control and conservation of their natural Enemies.

[38] Tanzubil, P. B. 1991. The control of insect pests of cowpea (Vigna unguiculata (L.) Walp) with neem (Azadirachta indica) in Northern Ghana. Tropical Pest Management, 37 (3): 216217.

[39] Oparaeke, A. M.1997. Evaluation of comparative efficacy of some plant powders for the control of Callosobruchus maculatus (F.) (Coleoptera: Bruchidae) on stored cowpea. Master's thesis, Ahmadu Bello University, Zaria, Nigeria. 105 pp.

[40] Dike, M. C.; Mshelia G. B. 1997. Laboratory assessment of the efficacy of Eucalyptus leaf powders in the control of Callosobruchus maculatus Fab. on stored cowpea.

[41] Javaid, S.; Dadson, R. B.; Hashem, F. M.; Joshi, J. M.; Arthur, L. A. 2004. Effect of spray applications, sowing dates and cultivar resistance on insect pests of cowpea in Delmarva Region of United State. [Abstract]. Journal of Sustainable $\begin{array}{llll}\text { Agriculture, } & 26 & \text { (3): }\end{array}$ https://doi.org/10.1300/J064v26n0307.

[42] Sokamè, B. M.; Tounou A. K.; Datinon, B.; Dannon, E. A.; Agboton, C.; Srinivasan, R.; Pittendrigh, B. R.; Tamò M. 2015. Combined activity of Maruca vitrata multinucleopolyhedrovirus MaviMNPV), and oil from neem, Azadirachta indica Juss and Jatropha curcas L., for the control of cowpea pests. Crop Protection, 72: 150-157.

[43] Nathan, S. Kalaivani, S., K., 2006. Combined effects of azadirachtin and nucleopolyhedrovirus (SpltNPV) on Spodoptera litura Fabricius (Lepidoptera: Noctuidae) larvae. Biological Control, 39: 96-104. 